\title{
Risk factors associated with secondary hyperparathyroidism in patients with chronic kidney disease
}

\author{
YUDAN WEI ${ }^{1 *}$, JING LIN $^{2 *}$, FAN YANG $^{3}$, XIUJIANG LI $^{4}$, YUE HOU $^{1}$, \\ RONGHUA LU ${ }^{5}$, XIAONV SHI ${ }^{1}$, ZHI LIU ${ }^{1}$ and YUJUN DU ${ }^{1}$ \\ ${ }^{1}$ Department of Nephrology, First Hospital of Jilin University, Changchun, Jilin 130021; \\ ${ }^{2}$ Department of Nephrology, The First Affiliated Hospital of Luohe Medical College, Luohe, Henan 462000; \\ ${ }^{3}$ Reproductive Center of the First Hospital of Jilin University; ${ }^{4}$ Department of Intensive Care Unit, Jilin Tumor Hospital, \\ Changchun, Jilin 130021; ${ }^{5}$ Department of Nephrology, Jilin City Central Hospital, Changchun, Jilin 132000, P.R. China
}

Received March 31, 2015; Accepted April 29, 2016

DOI: $10.3892 / \mathrm{etm} .2016 .3438$

\begin{abstract}
Secondary hyperparathyroidism (SHPT) is common in patients with chronic kidney disease (CKD), and its development and progression are affected by various factors. The aim of the present study was to identify the risk factors for SHPT in patients with CKD. A retrospective study was performed in 498 patients (305 males and 193 females) with CKD, observed in the The First Hospital of Jilin University between January 2008 and December 2012. The demographic, clinical and laboratory data were collected. Patients were divided into the SHPT group $(n=424)$ with elevated serum parathyroid hormone $(\mathrm{PTH})$ expression levels and the control group $(\mathrm{n}=74)$ with normal serum PTH expression levels. Univariate and multivariate regression analyses were employed to explore the risk factors for SHPT. Serum PTH expression levels in women with CKD were significantly higher than in men $(\mathrm{P}=0.047)$. Serum PTH expression levels were positively correlated with the expression levels of serum creatinine $(P<0.01)$, phosphorus $(\mathrm{P}<0.01)$, C-reactive protein $(\mathrm{P}<0.05)$, triglyceride $(\mathrm{P}<0.05)$, cholesterol $(\mathrm{P}<0.05)$ and low-density lipoprotein
\end{abstract}

Correspondence to: Dr Yujun Du, Department of Nephrology, First Hospital of Jilin University, 71 Xinmin Street, Changchun, Jilin 130021, P.R. China

E-mail:kjkduyujun@126.com

*Contributed equally

Abbreviations: SHPT, secondary hyperparathyroidism; CKD, chronic kidney disease; PTH, parathyroid hormone; $\mathrm{Hb}$, hemoglobin; $\mathrm{CO}_{2} \mathrm{CP}$, carbon dioxide combining power; TG, triglyceride; TC, cholesterol; HDL-C, high-density lipoprotein cholesterol; LDL-C, low-density lipoprotein cholesterol; CRP, C-reactive protein; MBD, mineral and bone disorder; FGF-23, fibroblast growth factor-23; PTHrP, parathyroid hormone-related protein; EPO, erythropoietin

Key words: chronic kidney disease, secondary hyperparathyroidism, risk factor, phosphorus, creatinine cholesterol $(\mathrm{P}<0.05)$, but were negatively correlated with the expression levels of hemoglobin $(\mathrm{P}<0.05)$, calcium $(\mathrm{P}<0.01)$ and $\mathrm{CO}_{2}$ combining power $(\mathrm{P}<0.01)$ in patients with $\mathrm{CKD}$. Multivariate analysis showed that the serum expression levels of creatinine $[\mu \mathrm{mol} / 1$; odds radio $(\mathrm{OR}), 1.003 ; 95 \%$ confidence interval (CI), 1.002-1.004; $\mathrm{P}=0.001]$ and phosphorus (mmol/l; OR, 2.19; 95\% CI, 1.254-3.826; $\mathrm{P}=0.006$ ) in patients with CKD significantly influenced serum PTH expression levels. The SHPT risk factors include female gender, low calcium, high phosphorus, acidosis, anemia, hypertension, hyperlipidemia and micro-inflammation, with blood phosphorus and creatinine being independent risk factors.

\section{Introduction}

The incidence of chronic kidney disease (CKD) is rapidly increasing, posing a serious health problem worldwide. More than 16 million adults are affected by end stage CKD in the USA $(1,2)$. Abnormal serum calcium, phosphorus and parathyroid hormone (PTH) expression levels are common challenges in the management of CKD $(3,4)$. These biochemical abnormalities, together with the dysregulation of vitamin D metabolism and bone turnover, constitute a systemic syndrome termed CKD mineral and bone disorder (CKD-MBD) (5).

Secondary hyperparathyroidism (SHPT) is a common complication of patients with CKD, which is characterized by increased blood PTH levels, and abnormal mineral and bone metabolism (6). It is associated with increased morbidity and mortality, and adversely influences the quality of life of patients with CKD $(3,6)$. The incidence of SHPT is reported to increase with the stage of CKD: $40 \%$ in stage 3,70\% in stage 4 and $>80 \%$ in stage $5(4,7)$.

The kidneys are vital organs regulating calcium and phosphorous homeostasis (8). SHPT is an adaptive pathophysiological process in response to deteriorating renal insufficiency (6). The fundamental mechanism of PTH in kidneys is to suppress the reabsorption of phosphate in the proximal tubule, and to stimulate calcium reabsorption in the ascending loop of Henle, distal tubule and collecting tubule (8). Upon the stimulation of PTH, renal calcium reabsorption and phosphate excretion are increased (9). Renal insufficiency 
leads to the dysregulation of calcium and phosphorous homeostasis, and results in reduced renal phosphate excretion and increased fibroblast growth factor-23 (FGF-23); the latter is a hormone that is primarily secreted by osteoblasts and osteocytes $(10,11)$. FGF-23 regulates circulating phosphate by decreasing sodium phosphate co-transporters in the proximal tubule of the kidneys. It also blocks the synthesis of serum vitamin $\mathrm{D}$ by inhibiting the expression of 25-dihydroxyvitamin D3 $1 \alpha$ hydroxylase $\left(1,25-(\mathrm{OH})_{2} \mathrm{D}_{3}\right)$ in the kidneys (12). These alterations further stimulate the production of PTH and hyperplasia of the parathyroid. In turn, these changes cause increasingly severe impairment of calcium and phosphorous metabolisms (13). If not properly managed, progressive SHPT can have severe consequences, and may lead to multi-system damages and malfunction of multiple organs that can result in bone disease, soft tissue calcification, vascular calcification and mortality (6).

The development and progression of SHPT is influenced by various factors. In addition to the well-recognized risk factors of impaired calcium and phosphorus metabolism and reduced $1,25-(\mathrm{OH})_{2} \mathrm{D}_{3}$ expression levels, numerous other factors have been implicated, such as anemia, acidosis, co-morbidities of cardiovascular disease and diabetes, and inflammation (6). In addition, SHPT itself is a risk factor for these pathophysiological conditions. Elevated PTH is associated with a greater prevalence and incidence of cardiovascular disease, and is an important cardiovascular disease risk factor (14). However, the complex interactions of these risk factors with SHPT remain unclear. In the current retrospective study, a large cohort of patients were recruited in order to analyze the association between risk factors influencing SHPT in patients with CKD, with a particular emphasis on laboratory biochemical measures. Early identification of risk factors could help prevent and treat SHPT in patients with CKD.

\section{Materials and methods}

Patients. The study protocol was reviewed and approved by the Institutional Review Committees of the First Hospital of Jilin University, Changchun, China. The data from 498 consecutive cases of CKD enrolled in The First Hospital of Jilin University between January 2008 and December 2012 was extracted and reviewed. Patients aged 10-74 years with an age-stratified estimated glomerular filtration rate of $20-70 \mathrm{ml} / \mathrm{min} / 1.73 \mathrm{~m}^{2}$ were included in the study. The inclusion criteria were as follows: i) Aged $\geq 18$ years and met the clinical practice guideline for chronic kidney disease [kidney disease outcome quality initiative (K/DOQI)] (15); ii) have complete laboratory measurements; and iii) cases with primary hyperparathyroidism were excluded from the study. The exclusion criteria included: i) Use of ossification, calcium or phosphorus in the past 3 months; ii) history of bleeding or transfusion in the past 3 months; iii) severe infection in the past 3 months; and iv) history of human immunodeficiency virus infection, primary liver disease, cancer or autoimmune diseases.

Study design. Demographic and clinical data were extracted from all patients with a confirmed diagnosis of CKD, including age, gender, body mass index, history of hypertension, diabetes, primary disease and other clinical data. Laboratory values were also collected from all patients with CKD. Based on serum PTH expression levels, the patients were divided into two groups: The SHPT group with elevated PTH expression levels $(>88 \mathrm{pg} / \mathrm{ml})$ and the control group with normal PTH expression levels $(<88 \mathrm{pg} / \mathrm{ml})$.

Laboratory measures. After overnight fasting, blood samples were drawn using uniform techniques during the early morning in The First Hospital of Jilin University. The laboratory measurements included serum creatinine, hemoglobin $(\mathrm{Hb})$, carbon dioxide combining power $\left(\mathrm{CO}_{2} \mathrm{CP}\right)$, triglyceride (TG), cholesterol (TC), high-density lipoprotein cholesterol (HDL-C), low-density lipoprotein cholesterol (LDL-C), C-reactive protein (CRP), serum albumin, serum calcium and phosphorus. CRP was detected using a turbidimetric immunoassay method (Siemens BN II; Siemens AG, Berlin, Germany). PTH was detected using a chemiluminescence method using Beckman DXI800 (Beckman Coulter, Inc., Indianapolis, IN, USA). $24 \mathrm{~h}$ urinary protein was detected using a pyrogallol red molybdate complex method (16). Serum PTH, calcium and phosphorus levels were measured using methods described previously (17). Hb levels were determined using sodium dodecyl sulfate hemoglobin determination (18). Other laboratory values were measured by standard methods according to the manufacturer's protocol using an auto analyzer (Hitachi 7600-210; Hitachi, Ltd., Tokyo, Japan).

Statistical analysis. SPSS version 19.0 software (IBM SPSS, Armonk, NY, USA) was used for all statistical analyses. Results are presented as the mean \pm standard deviation for continuous variables. Student's t-test was used for comparisons between two groups with normal distributions, and the Wilcoxon-Mann-Whitney $U$ test was used for groups with non-normal distributions. $\chi^{2}$ test was used to analyze the differences between categorical data. Linear correlation analysis was performed to examine the association between serum PTH expression levels and the expression levels of other laboratory parameters; Pearson's correlation coefficients are presented. Multivariate logistic regression analysis was used to analyze the risk factors for SHPT. $\mathrm{P}<0.05$ was considered to indicate a statistically significant difference.

\section{Results}

Patient characteristics. A total of 498 patients with a confirmed diagnosis of CKD were included in this retrospective study, including 305 males and 193 females (male to female ratio, 1.58:1). The mean age was 49.75 years (40-59 years). There were 424 patients with elevated PTH expression levels and 74 patients with normal serum PTH expression levels. The main causes of CKD were primary glomerular disease (53.61\%), diabetic nephropathy (16.67\%), hypertensive nephropathy $(8.84 \%)$, chronic interstitial nephritis $(7.03 \%)$, polycystic kidney $(3.41 \%)$ and others $(10.44 \%)$. The co-morbid conditions included hypertension $(83.13 \%)$ and diabetes mellitus (16.67\%).

Comparisons of demographic and clinical characteristics between patients with normal PTH and elevated PTH expression levels. The differences in demographic and clinical 
Table I. Univariate analyses in patients with chronic kidney disease.

\begin{tabular}{|c|c|c|c|c|c|}
\hline \multirow[b]{2}{*}{ Variable } & \multicolumn{2}{|c|}{ Control } & \multicolumn{2}{|c|}{ SHPT } & \multirow[b]{2}{*}{ P-value } \\
\hline & No. of patients & $\%$ & No. of patients & $\%$ & \\
\hline Total $(n=498)$ & 74 & 100 & 424 & 100 & \\
\hline Age, years $($ mean $\pm S D)$ & $51.26 \pm 15.74$ & & $49.45 \pm 16.33$ & & 0.476 \\
\hline Gender & & & & & $0.047^{\mathrm{a}}$ \\
\hline Male & 53 & 71.62 & 252 & 59.43 & \\
\hline Female & 21 & 28.38 & 172 & 40.57 & \\
\hline Underlying cause & & & & & 0.445 \\
\hline Primary glomerular diseases & 41 & 55.41 & 226 & 53.30 & \\
\hline Diabetic nephropathy & 2 & 2.70 & 31 & 7.31 & \\
\hline Hypertensive nephropathy & 12 & 16.22 & 70 & 16.51 & \\
\hline Chronic interstitial nephritis & 8 & 10.81 & 36 & 8.49 & \\
\hline Polycystic kidney & 1 & 1.35 & 26 & 6.13 & \\
\hline Other & 10 & 13.51 & 42 & 9.91 & \\
\hline \multicolumn{6}{|l|}{ Co-morbid condition } \\
\hline Hypertension & 54 & 72.91 & 360 & 84.91 & $0.011^{\mathrm{a}}$ \\
\hline
\end{tabular}

${ }^{\mathrm{a}} \mathrm{P}<0.05$. P values were obtained from comparisons between the SHPT and control group. SHPT, secondary hyperparathyroidism; SD, standard deviation.

characteristics between the normal PTH and elevated PTH groups in patients with CKD were compared and the results are presented in Table I. The age distribution had no significant difference between the control and SHPT groups (51.26 \pm 15.74 vs. $49.45 \pm 16.33$ years; $\mathrm{P}=0.476)$. However, the difference in gender between the two groups was significant $(\mathrm{P}=0.047)$; $71.62 \%$ were male in the normal PTH group and $59.43 \%$ were male in the SHPT group. Female patients accounted for 28.38 and $40.57 \%$ in the two groups, respectively, indicating that increased PTH occurred more frequently in women than in men.

Primary underlying diseases had no significant effect on PTH expression levels $(\mathrm{P}=0.445)$. The disease distributions were similar in the control and SHPT groups: Primary glomerular diseases (55.41 vs. 53.30\%), diabetic nephropathy (2.70 vs. $7.31 \%)$, hypertensive nephropathy (16.2 vs. $16.5 \%)$ and chronic interstitial nephritis (10.8 vs. $8.49 \%$ ). The presence of co-morbid hypertension was significantly different between the two groups (73.00 vs. $84.9 \%$; $\mathrm{P}<0.05$; Table I)

Comparisons of laboratory biochemical markers between patients with normal and elevated PTH expression levels. The differences in the laboratory biochemical measurements between the two groups were analyzed. Compared with the control group, the mean serum expression levels of creatinine, CRP, TG, TC and LDL-C were significantly increased, and the mean levels of hemoglobin and $\mathrm{CO}_{2} \mathrm{CP}$ were significantly decreased, in the elevated PTH group (all $\mathrm{P}<0.05$ ). However, the values of serum albumin and $24 \mathrm{~h}$ urinary protein were not significantly different between the two groups $(\mathrm{P}>0.05)$. Compared with the normal PTH group, the mean calcium levels were significantly decreased and the mean phosphorus levels were significantly increased in patients with elevated PTH expression levels (both $\mathrm{P}<0.01$; Table II)

Multivariate analysis of risk factors influencing SHPT. A multivariate logistic regression analysis was performed in order to identify independent factors of SHPT. The results demonstrated that the serum creatinine $[\mu \mathrm{mol} / \mathrm{l}$; odds $\mathrm{radio}$ (OR), 1.003; 95\% confidence interval (CI), 1.002-1.004; $\mathrm{P}=0.001)$ and serum phosphorus (mmol/1; OR, 2.19; 95\% CI, 1.254-3.826; $\mathrm{P}=0.006)$ were independent risk factors for SHPT (Table III).

Correlation analysis of serum PTH expression levels with biochemical markers in patients with CKD. Correlation analyses were performed in order to analyze the associations between serum PTH with laboratory biochemical measurements in patients with CKD. As presented in Table IV, the results indicated that serum $\mathrm{PTH}$ expression levels were positively correlated with the expression levels of serum creatinine $(\mathrm{P}<0.01)$, phosphorus $(\mathrm{P}<0.01), \mathrm{CRP}(\mathrm{P}<0.001)$, TG $(\mathrm{P}<0.001)$, TC $(\mathrm{P}<0.001)$ and LDL-C $(\mathrm{P}=0.011)$, and negatively correlated with the expression levels of blood hemoglobin $(\mathrm{P}=0.025)$, calcium $(\mathrm{P}<0.001)$ and $\mathrm{CO}_{2} \mathrm{CP}(\mathrm{P}<0.001)$. There were no significant correlations between the PTH expression levels and serum albumin, HDL-C or $24 \mathrm{~h}$ urinary protein in these patients $(\mathrm{P}>0.05$; Table IV).

\section{Discussion}

SHPT is a progressive and severe complication frequently associated with CKD. The development and progression is affected by several factors associated with various mechanisms (6). To determine the risk factors of SHPT in patients with CKD, a 
Table II. Univariate analyses of biochemical factors affecting SHPT in patients with chronic kidney disease.

\begin{tabular}{lccc}
\hline Variable & Control $^{\mathrm{a}}$ & SHPT $^{\mathrm{a}}$ & P-value \\
\hline Serum albumin $(\mathrm{g} / \mathrm{dl})$ & $32.59 \pm 7.56$ & $31.48 \pm 6.47$ & 0.189 \\
Serum creatinine $(\mu \mathrm{mol} / \mathrm{l})$ & $241.45 \pm 235.33$ & $699.30 \pm 350.17$ & $<0.001^{\mathrm{b}}$ \\
Blood hemoglobin $(\mathrm{g} / \mathrm{dl})$ & $117 \pm 27.36$ & $88.50 \pm 24.96$ & $<0.001^{\mathrm{b}}$ \\
$\mathrm{CO}_{2} \mathrm{CP}(\mathrm{mmol} / \mathrm{l})$ & $23.73 \pm 4.22$ & $21.04 \pm 4.96$ & $<0.001^{\mathrm{b}}$ \\
C-reactive protein $(\mathrm{g} / \mathrm{l})$ & $1.76 \pm 10.16$ & $3.11 \pm 14.41$ & $0.018^{\mathrm{c}}$ \\
Triglyceride $(\mathrm{mmol} / \mathrm{l})$ & $1.23 \pm 1.14$ & $1.58 \pm 0.92$ & $0.024^{\mathrm{c}}$ \\
Cholesterol $(\mathrm{mmol} / \mathrm{l})$ & $4.20 \pm 1.29$ & $4.65 \pm 1.29$ & $0.016^{\mathrm{c}}$ \\
LDL-C $(\mathrm{mmol} / \mathrm{l})$ & $2.49 \pm 0.95$ & $2.80 \pm 0.91$ & $0.028^{\mathrm{c}}$ \\
HDL-C (mmol/l) & $1.18 \pm 0.67$ & $1.14 \pm 0.49$ & 0.107 \\
Urinary protein $(\mathrm{g} / 24 \mathrm{~h})$ & $3 \pm 3.37$ & $2.35 \pm 4.43$ & 0.64 \\
Calcium $(\mathrm{mmol} / \mathrm{l})$ & $2.16 \pm 0.23$ & $1.98 \pm 1.58$ & $0.024^{\mathrm{c}}$ \\
Phosphorus $(\mathrm{mmol} / \mathrm{l})$ & $1.48 \pm 0.42$ & $1.88 \pm 0.62$ & $<0.001^{\mathrm{b}}$ \\
PTH $(\mathrm{pg} / \mathrm{ml})$ & $435.99 \pm 380.84$ & $49.86 \pm 22.83$ & $<0.001^{\mathrm{b}}$ \\
\hline
\end{tabular}

SHPT, secondary hyperparathyroidism; $\mathrm{CO}_{2} \mathrm{CP}$, carbon dioxide combining power; LDL-C, low-density lipoprotein cholesterol; HDL-C, high-density lipoprotein cholesterol; $\mathrm{PTH}$, parathyroid hormone. ${ }^{\mathrm{a}}$ Expressed as the mean \pm standard deviation; ${ }^{\mathrm{b}} \mathrm{P}<0.01 ;{ }^{\mathrm{c}} \mathrm{P}<0.05$.

Table III. Multivariate analysis of risk factors influencing secondary hyperparathyroidism in 498 patients with chronic kidney disease.

\begin{tabular}{lcccc}
\hline & & \multicolumn{2}{c}{$95 \%$ CI } & \\
\cline { 3 - 4 } Variable & Odds ratio & Lower & Upper & P-value \\
\hline Gender & 1.561 & 0.836 & 2.916 & 0.162 \\
Blood pressure & 1.931 & 0.098 & 3.739 & 0.051 \\
Hemoglobin & 0.994 & 0.982 & 1.006 & 0.348 \\
Serum creatinine & 1.003 & 1.002 & 1.004 & $0.001^{\text {a }}$ \\
Serum calcium & 0.976 & 0.379 & 2.891 & 0.321 \\
Serum phosphorus & 2.190 & 1.254 & 3.826 & $0.006^{\mathrm{a}}$ \\
CO ${ }_{2}$ CP & 0.945 & 0.886 & 1.008 & 0.086 \\
C-reactive protein & 1.994 & 0.989 & 1.091 & 0.591 \\
Triglyceride & 0.926 & 0.689 & 1.244 & 0.608 \\
Cholesterol & 0.291 & 0.644 & 1.317 & 0.651 \\
LDL-C & 0.918 & 0.620 & 1.545 & 0.925
\end{tabular}

$\mathrm{CI}$, confidence interval; $\mathrm{CO}_{2} \mathrm{CP}$, carbon dioxide combining power; LDL-C, low-density lipoprotein cholesterol; ${ }^{\mathrm{a}} \mathrm{P}<0.01$.

retrospective study with a large cohort of patients who were clinically diagnosed with CKD was conducted. The elevated serum PTH expression levels were shown to be positively correlated with the severity of hyperparathyroidism. Based on serum PTH expression levels, patients were divided into normal PTH and elevated PTH expression level groups. For patients with elevated PTH expression levels, primary hyperparathyroidism cases were excluded prior to enrollment in the study. The present study demonstrated that $85.14 \%$ patients with CKD had elevated serum PTH expression levels, which was similar to that in previous reports $(7,19)$. Andress et al $(7)$ reported that $\sim 40 \%$ patients with CKD stage 3 and $80 \%$ of
Table IV. Correlation analysis of parathyroid hormone with biochemical markers in 498 patients with chronic kidney disease.

\begin{tabular}{lcc}
\hline Variable & R-value & P-value \\
\hline Serum creatinine & 0.161 & $<0.001^{\mathrm{a}}$ \\
Phosphorus & 0.632 & $<0.001^{\mathrm{a}}$ \\
C reactive protein & 0.151 & $<0.001^{\mathrm{a}}$ \\
Triglyceride & 0.193 & $<0.001^{\mathrm{a}}$ \\
Cholesterol & 0.166 & $<0.001^{\mathrm{a}}$ \\
LDL-C & 0.138 & $0.011^{\mathrm{b}}$ \\
Hemoglobin & -0.285 & $0.025^{\mathrm{b}}$ \\
Calcium & -0.825 & $<0.001^{\mathrm{a}}$ \\
CO ${ }_{2} \mathrm{CP}$ & -0.232 & $<0.001^{\mathrm{a}}$ \\
Serum albumin & -0.029 & 0.515 \\
HDL-C & -0.014 & 0.749 \\
24 h urinary protein & -0.120 & 0.107 \\
\hline
\end{tabular}

LDL-C, low-density lipoprotein cholesterol; $\mathrm{CO}_{2} \mathrm{CP}$, carbon dioxide combining power; HDL-C, high-density lipoprotein cholestrol. ${ }^{\mathrm{a}} \mathrm{P}<0.01 ;{ }^{\mathrm{b}} \mathrm{P}<0.05$.

patients with CKD stage 4 are affected by SHPT. Drüeke (19) reported that SHPT is observed in $20-80 \%$ patients with CKD, depending on the stages of the disease.

In the present study, it was observed that elevated PTH was more commonly observed in women compared with men, suggesting that there is a significant gender difference in PTH elevation. A previous study suggested that the elevated estrogen and estrogen receptor expression levels upregulate the mRNA expression levels of PTH in parathyroid cells (20), which may explain the gender difference in the development of SHPT. 
Among the underlying diseases causing CKD, primary glomerulonephritis remains the leading cause of CKD (21). The disease accounted for $53.61 \%$ of the cases in the present study, which is similar to previous studies that reported $55 \%(3,4)$. Hypertension is a risk factor of CKD and also a common complication of CKD $(22,23)$. With the progression of CKD, $80-85 \%$ patients have elevated blood pressure. The current study demonstrated that $83.14 \%$ patients with CKD had hypertension, and the majority of these hypertensive patients had SHPT. A previous study (24) has suggested that elevation of PTH expression levels in patients with end-stage kidney disease increases cytoplasmic calcium concentration in vascular smooth muscle cells and thereby promotes vessel contraction. The enhanced resistance of peripheral vessel increases blood pressure. In turn, hypertension stimulates the secretion of PTH and promotes the progression of secondary hyperparathyroidism. This cycle accelerates the deterioration of renal insufficiency.

Blood phosphorus expression levels are one of the most important factors stimulating the synthesis and secretion of PTH in patients with CKD (25). With worsening renal function, the excretion of phosphorus from renal tubular decreases and blood phosphorus levels increase (25). The results from the present study demonstrated that hyperphosphatemia was an independent risk factor influencing the development of SPTH. Voormolen et al (26) reported that elevated plasma phosphorus directly stimulates the synthesis and secretion of PTH in patients with stage 4-5 CKD. The effect of plasma phosphorus is independent of the level of plasma calcium or the activation of vitamin D. The results in the current study were in line with this report, indicating that hyperphosphatemia is an independent risk factor affecting renal function in patients with CKD.

Blood calcium expression levels are another important factor affecting PTH in patients with CKD (27). In the present study, univariate analyses showed that the blood calcium expression levels were significantly lower in patients with elevated PTH expression levels compared with in patients with normal PTH expression levels $(\mathrm{P}<0.05)$. Unlike the plasma phosphorus expression levels, the plasma calcium expression levels were not an independent risk factor for the elevation of PTH.

Serum creatinine expression levels are a commonly used index indirectly assessing the renal function of patients, and the rising of serum creatinine predicts the worsening of renal function (28). According to the K/DOQI guidelines (15), once the glomerular filtration rate of patients with CKD is $<60 \mathrm{ml} / \mathrm{min}$, PTH expression levels increase and calcium expression levels decrease. Previous reports $(15,29)$ have suggested that PTH elevation is negatively correlated with the reduction of the glomerular filtration rate. The results of the present study demonstrated that PTH is negatively correlated with serum creatinine expression levels in patients with CKD. In addition, multivariate analysis revealed that serum creatinine expression levels are an independent risk factor for SHPT. Metabolic acidosis is common in patients with chronic renal insufficiency. Due to the decline of hydrogen excretion or $\mathrm{HCO}_{3}$ reabsorption in renal tubular, phosphoric acid, sulfuric acid and other acidic substances are retained inside the body $(30,31)$. Acidosis inhibits the activity of $1-\alpha$ hydroxylase in the proximal tubule, and thereby inhibits the synthesis of $1,25-(\mathrm{OH})_{2} \mathrm{D}_{3}$. Disthabanchong et al (32) suggested that metabolic acidosis promotes the response to PTH in UMR 106-01 osteoblast-like cells, and that the effect is mediated by increasing the mRNA expression levels of the PTH/PTHrP receptor.

The $\mathrm{C}$ reactive protein is the most recognized inflammatory protein (33) and has been widely used to monitor the inflammatory responses in patients. Previous studies have suggested that microinflammation exists in patients with CKD $(34,35)$; with the deterioration of renal insufficiency, microinflammation increases, resulting in glomerular sclerosis and the weakening of renal tubular elasticity. The release of various inflammatory mediators further promote the proliferation of glomerular mesangial cells, increase endothelial cell permeability, stimulate the production of white blood cells, and promote the release of superoxide and proteolytic enzymes $(34,35)$. These changes further deteriorate renal function and aggravate the elevation of PTH (36).

Renal anemia is a common complication of CKD. The incidence of renal anemia increases significantly following stage 3 CKD (37). The severity of anemia indirectly reflects renal dysfunction. In the present study, it was observed that the serum PTH expression levels were negatively correlated with blood hemoglobin expression levels in patients with CKD. PTH is considered to be a uremic toxin, as it directly inhibits the hematopoietic function of bone marrow, increases the fragility of erythrocytes and shortens the life expectancy of erythrocytes (38). SHPT can also increase erythropoietin resistance (39). In addition, SHPT-induced bone damage results in the proliferation of fibroblasts and fibrosis of bone marrow, leading to secondary anemia (40). These mechanisms likely underlie the frequently occurring anemia in patients with CKD.

Abnormal lipid metabolism is common in patients with $\mathrm{CKD}$, and is the most important risk factor for CKD-associated cardiovascular disease (41). In addition, lipid deposition has a direct toxic effect on renal function (42). Previous reports suggest that, in addition to proteinuria and hypertension, hyperlipidemia is the third important risk factor for CKD (43). Abnormal lipid metabolism and deposition are associated with microinflammation and oxidative stress (44). The current study demonstrated that PTH is positively correlated with the expression levels of serum TG, TC and LDL-C in patients with CKD, suggesting that hyperlipidemia is closely associated with SHPT.

Whereas previous studies have primarily focused on the analysis of traditional risk factors of SHPT, the current study analyzed multiple factors influencing the occurrence and development of SHPT $(25,45,46)$. However, this retrospective study had a number of limitations. The selected patients were in different stages of renal insufficiency, which may influence the results of analysis. In addition, the sample size of the normal PTH expression level group was relatively small, which may have an impact on the correlation analyses.

In conclusion, the development of SHPT in patients with CKD is affected by numerous risk factors, including female gender, low expression levels of calcium, high expression levels of phosphorus, acidosis, anemia, hypertension, hyperlipidemia and $\mathrm{C}$ reactive protein. Serum phosphorus and serum 
creatinine are independent risk factors for SHPT. SHPT is likely to be the result of complex interactions among these factors. Early identification of the risk factor is beneficial to the prevention and treatment of CKD.

\section{Acknowledgements}

The authors thank Medjaden Bioscience Limited for assisting in the preparation of the manuscript.

\section{References}

1. Coresh J, Selvin E, Stevens LA, Manzi J, Kusek JW, Eggers P, Van Lente F and Levey AS: Prevalence of chronic kidney disease in the United States. JAMA 298: 2038-2047, 2007.

2. Centers for Disease Control and Prevention: Prevalence of chronic kidney disease and associated risk factors - United States, 1999-2004. MMWR Morb Mortal Wkly Rep 56: 161-165, 2007.

3. Melamed ML, Eustace JA, Plantinga L, Jaar BG, Fink NE, Coresh J, Klag MJ and Powe NR: Changes in serum calcium, phosphate, and PTH and the risk of death in incident dialysis patients: A longitudinal study. Kidney Int 70: 351-357, 2006.

4. Levin A, Bakris GL, Molitch M, Smulders M, Tian J, Williams LA and Andress DL: Prevalence of abnormal serum vitamin D, PTH, calcium, and phosphorus in patients with chronic kidney disease: Results of the study to evaluate early kidney disease. Kidney Int 71: 31-38, 2007

5. Moe S, Drüeke T, Cunningham J, Goodman W, Martin K, Olgaard K, Ott S, Sprague S, Lameire N and Eknoyan G; Kidney Disease: Improving Global Outcomes (KDIGO): Definition, evaluation, and classification of renal osteodystrophy: A position statement from Kidney Disease: Improving Global Outcomes (KDIGO). Kidney Int 69: 1945-1953, 2006.

6. Cunningham J, Locatelli F and Rodriguez M: Secondary hyperparathyroidism: Pathogenesis, disease progression, and therapeutic options. Clin J Am Soc Nephrol 6: 913-921, 2011

7. Andress DL, Coyne DW, Kalantar-Zadeh K, Molitch ME, Zangeneh F and Sprague SM: Management of secondary hyperparathyroidism in stages 3 and 4 chronic kidney disease. Endocr Pract 14: 18-27, 2008

8. Fukagawa M, Hamada Y, Nakanishi S and Tanaka M: The kidney and bone metabolism: Nephrologists' point of view. J Bone Miner Metab 24: 434-438, 2006

9. Li J, Molnar MZ, Zaritsky JJ, Sim JJ, Streja E, Kovesdy CP, Salusky I and Kalantar-Zadeh K: Correlates of parathyroid hormone concentration in hemodialysis patients. Nephrol Dial Transplant 28: 1516-1525, 2013.

10. Liu S, Guo R, Simpson LG, XiaoZS, Burnham CEand Quarles LD: Regulation of fibroblastic growth factor 23 expression but not degradation by PHEX. J Biol Chem 278: 37419-37426, 2003.

11. Riminucci M, Collins MT, Fedarko NS, Cherman N, Corsi A, White KE, Waguespack S, Gupta A, Hannon T, Econs MJ, et al FGF-23 in fibrous dysplasia of bone and its relationship to renal phosphate wasting. J Clin Invest 112: 683-692, 2003.

12. Shimada T, Hasegawa H, Yamazaki Y, Muto T, Hino R, Takeuchi Y, Fujita T, Nakahara K, Fukumoto S and Yamashita T: FGF-23 is a potent regulator of vitamin D metabolism and phosphate homeostasis. J Bone Miner Res 19: 429-435, 2004

13. Slatopolsky E, Brown A and Dusso A: Pathogenesis of secondary hyperparathyroidism. Kidney Int Suppl 73 (S73): S14-S19, 1999.

14. Anderson JL, Vanwoerkom RC, Horne BD, Bair TL, May HT, Lappé DL and Muhlestein JB: Parathyroid hormone, vitamin D, renal dysfunction, and cardiovascular disease: Dependent or independent risk factors? Am Heart J 162: 331-339.e2, 2011

15. National Kidney Foundation: K/DOQI clinical practice guidelines for bone metabolism and disease in chronic kidney disease. Am J Kidney Dis 42 (4 Suppl 3): S1-S201, 2003.

16. Orsonneau JL, Douet P, Massoubre C, Lustenberger P and Bernard S: An improved pyrogallol red-molybdate method for determining total urinary protein. Clin Chem 35: 2233-2236, 1989.

17. Moe SM, Chertow GM, Coburn JW, Quarles LD, Goodman WG, Block GA, Drüeke TB, Cunningham J, Sherrard DJ, McCary LC, et al: Achieving NKF-K/DOQI bone metabolism and disease treatment goals with cinacalcet $\mathrm{HCl}$. Kidney Int 67: 760-771, 2005
18. Karsan A, Maclaren I, Conn D and Wadsworth L: An evaluation of hemoglobin determination using sodium lauryl sulfate. AmJ Clin Pathol 100: 123-126, 1993.

19. Drüeke TB: Cell biology of parathyroid gland hyperplasia in chronic renal failure. J Am Soc Nephrol 11: 1141-1152, 2000

20. Prince RL: Counterpoint: Estrogen effects on calcitropic hormones and calcium homeostasis. Endocr Rev 15: 301-309, 1994.

21. Li LS and Liu ZH: Epidemiologic data of renal diseases from a single unit in China: analysis based on 13,519 renal biopsies. Kidney Int 66: 920-923, 2004.

22. Tsai WC, Wu HY, Peng YS, Ko MJ, Wu MS, Hung KY, Wu KD, Chu TS and Chien KL: Risk factors for development and progression of chronic kidney disease: A systematic review and exploratory meta-analysis. Medicine (Baltimore) 95: e3013, 2016.

23. Staples A and Wong C: Risk factors for progression of chronic kidney disease. Curr Opin Pediatrics 22: 161-169, 2010.

24. Ferrier KE, Muhlmann MH, Baguet JP, Cameron JD, Jennings GL, Dart AM and Kingwell BA: Intensive cholesterol reduction lowers blood pressure and large artery stiffness in isolated systolic hypertension. J Am Coll Cardiol 39: 1020-1025, 2002.

25. Hruska KA and Mathew S: The roles of the skeleton and phosphorus in the CKD mineral bone disorder. Adv Chronic Kidney Dis 18: $98-104,2011$

26. Voormolen N, Noordzij M, Grootendorst DC, Beetz I, Sijpkens YW, van Manen JG, Boeschoten EW, Huisman RM, Krediet RT and Dekker FW; PREPARE study group: High plasma phosphate as a risk factor for decline in renal function and mortality in pre-dialysis patients. Nephrol Dial Transplant 22: 2909-2916, 2007.

27. Goodman WG and Quarles LD: Development and progression of secondary hyperparathyroidism in chronic kidney disease: Lessons from molecular genetics. Kidney Int 74: 276-288, 2008.

28. Smith GL, Shlipak MG, Havranek EP, Foody JM, Masoudi FA, Rathore SS and Krumholz HM: Serum urea nitrogen, creatinine, and estimators of renal function: mortality in older patients with cardiovascular disease. Arch Intern Med 166: 1134-1142, 2006.

29. Kidney Disease; Improving Global Outcomes (KDIGO) CKD-MBD Work Group: KDIGO clinical practice guideline for the diagnosis, evaluation, prevention, and treatment of Chronic Kidney Disease-Mineral and Bone Disorder (CKD-MBD). Kidney Int 76 (Suppl 113): S1-S130, 2009.

30. Ortega LM and Arora S: Metabolic acidosis and progression of chronic kidney disease: incidence, pathogenesis, and therapeutic options. Nefrologia 32: 724-730, 2012.

31. Kovesdy CP: Metabolic acidosis and kidney disease: does bicarbonate therapy slow the progression of CKD? Nephrol Dial Transplant 27: 3056-3062, 2012

32. Disthabanchong S, Martin KJ, McConkey CL and Gonzalez EA: Metabolic acidosis up-regulates PTH/PTHrP receptors in UMR 106-01 osteoblast-like cells. Kidney Int 62: 1171-1177, 2002.

33. Lavín-Gómez BA, Palomar-Fontanet R, Gago-Fraile M, Quintanar-Lartundo JA, Gómez-Palomo E, González-Lamuño D, García-Unzueta MT, Arias-Rodríguez MA and Gómez-Gerique JA: Inflammation markers, chronic kidney disease, and renal replacement therapy. Adv Perit Dial 27: 33-37, 2011.

34. Tsirpanlis G, Bagos P, Ioannou D, Bleta A, Marinou I, Lagouranis A, Chatzipanagiotou S and Nicolaou C: Exploring inflammation in hemodialysis patients: Persistent and superimposed inflammation. A longitudinal study. Kidney Blood Press Res 27: 63-70, 2004.

35. Ojeda R and Aljama PA: Chronic microinflammation and endothelial damage in uremia. Nefrologia 28: 583-586, 2008 (In Spanish).

36. Shimada K, Kawarabayashi T, Tanaka A, Fukuda D, Nakamura Y, Yoshiyama M, Takeuchi K, Sawaki T, Hosoda K and Yoshikawa J: Oolong tea increases plasma adiponectin levels and low-density lipoprotein particle size in patients with coronary artery disease. Diabetes Res Clin Pract 65: 227-234, 2004.

37. Iseki $\mathrm{K}$ and Kohagura $\mathrm{K}$ : Anemia as a risk factor for chronic kidney disease. Kidney Int Suppl: S4-S9, 2007.

38. Urena P, Eckardt KU, Sarfati E, Zingraff J, Zins B, Roullet JB, Roland E, Drüeke T and Kurtz A: Serum erythropoietin and erythropoiesis in primary and secondary hyperparathyroidism: Effect of parathyroidectomy. Nephron 59: 384-393, 1991.

39. Drüeke TB and Eckardt KU: Role of secondary hyperparathyroidism in erythropoietin resistance of chronic renal failure patients. Nephrol Dial Transplant 17 (Suppl 5): 28-31, 2002. 
40. Strutz F and Zeisberg M: Renal fibroblasts and myofibroblasts in chronic kidney disease. J Am Soc Nephrol 17: 2992-2998, 2006.

41. Attman PO, Samuelsson O and Alaupovic P: Lipoprotein metabolism and renal failure. Am J Kidney Dis 21: 573-592, 1993.

42. Bobulescu IA: Renal lipid metabolism and lipotoxicity. Curr Opin Nephrol Hypertens 19: 393-402, 2010.

43. Sandhu S, Wiebe N, Fried LF and Tonelli M: Statins for improving renal outcomes: A meta-analysis. J Am Soc Nephrol 17: 2006-2016, 2006.
44. Morena M,Cristol JP, Senécal L,Leray-Moragues H,KrieterD and Canaud B: Oxidative stress in hemodialysis patients: Is NADPH oxidase complex the culprit? Kidney Int Suppl 61: 109-114, 2002.

45. Williams ME: Chronic kidney disease/bone and mineral metabolism: the imperfect storm. Semin Nephrol 29: 97-104, 2009.

46. Bover J, Aguilar A, Baas J, Reyes J, Lloret MJ, Farré N, Olaya M, Canal C, Marco H, Andrés E, Trinidad P and Ballarin J: Calcimimetics in the chronic kidney disease-mineral and bone disorder. Int J Artif Organs 32: 108-121, 2009. 